\title{
COYOTE MANAGEMENT IN SASKATCHEWAN: IS POISON THE ANSWER?
}

\author{
by Nora M. Stewart, R.R. \#2, Craven
}

The dog vomited, writhed, ran blindly into walls, convulsed, and, after about 20 minutes of agony, lay still. He had been a companion, house guard, and hunting dog, friendly and harmless, but now he was dead. Why and how, especially here in the Qu'Appelle Valley, a mile from the nearest neighbour? Could it be that poison bait was being put out "legitimately" to control coyotes, or did someone deliberately poison our dog? As we began asking questions of neighbours, municipal officials, police, and Department of Natural Resources (DNR) personnel, it became apparent that legal aspects of poisoning were poorly defined, and scientific ones misunderstood. Although it was obvious that we were going to get no satisfactory answer as to how our dog died, I felt compelled to investigate further, and to write the following article summarizing my findings.

Late in the fall, on the decision of municipal councils and with the written permission of landowners, poison bait is set out in various parts of Saskatchewan to control coyotes (and wolves). Warning signs are placed nearby, and notices of. the locations are placed in the local newspapers. DNR provides the poison, equipment and manpower, warning posters, and landowner agreement forms; does the paper work involved in keeping track of bait handling; and pays conservation officers' expenses. The municipality pays for the acquisition of meat for bait (usually a horse or sheep); for handling baits, including cutting up, distributing in late fall, and destroying in spring; and advertising bait locations. To my knowledge, no one has provided a figure for the annual cost to the taxpayer. Even if a figure were available, it would have to be examined closely, because such figures often exclude overhead costs, and these can far exceed the "obvious" expenses.

The poison available to the municipalities is compound 1080 , sodium monofluoroacetate. In describing it, United States Senator Gaylord Nelson (1970) of Wisconsin, introducing a bill to establish a national policy with respect to predatory wild animals, says: " 1080 is a slow degrading poison that attacks the central nervous system. A coyote, or an animal of similar size, like a dog, can be killed by a dose of 1.4 ounces of treated bait. After eating the poisoned bait, an animal may feel nothing for about thirty minutes, but it will ordinarily die within a few hours, after violent convulsions and vomiting. Because it keeps on moving, the dying animal often vomits deadly bits of undigested meat over a wide area-forming new bait for birds and other animals." This evidence is confirmed by Smelser (1959) in her article which strongly condemns the use of 1080 in the United States.

In the Saskatchewan DNR information booklet "Coyote Control Program 1968-69" (which is not to be made available to the general public-I was told it might cause unnecessary alarm), the figure of $3 \mathrm{oz}$. of bait to kill a coyote is given, but even this is less than one-quarter cupful. The poison is so toxic that those handling it are advised not to leave bait where it might thaw and drip (en route to its placement destination), because animals such as dogs and cats licking these spots "will in all likelihood die from the effects of the poison."

The poison acquired its name because it was the 1080th experiment undertaken in a Denver, Colorado laboratory to produce an efficient rodenticide. This is stated in DNR's own Coyote Control booklet, and yet three different officials at DNR have told me that 1080 is a selective poison 
for canines. Actually, the list of victim species is endless. Phillips (1971), lists ferrets, foxes, wolverines, hawks, owls, eagles, mountain lions, bobcats, prairie dogs, skunks, badgers and porcupines. Smelser (1959) adds mink and marten. Perry (1970) quotes a retired trapper who observed magpies, Canada jays, Clark's Nutcrackers, and woodpeckers feeding on 1080 bait stations and "these can carry pieces off and pack it away where weasels can find it."

Another misconception about 1080 which I heard from several people involved in the poison program here is that 1080 has very limited secondary effects; that is, that other creatures eating poisoned animals would not be affected. The DNR information booklet itself notes secondary effects on dogs, cats, rodents, pigs, and carnivorous wild animals, and hence stresses the need for the collection of "all surface kill that can be located"but of course most animals could run or wander miles from the bait and never be discovered (Smelser, 1959; Phillips, 1971). Perry (1970) quotes the Western Montana Scientists Committee for Public Information: "As 1080 remains stable and does not degrade easily, it is extremely hazardous to animals higher in the food chain." Foxes, skunks, coyotes, eagles, ravens, magpies and jays have died of secondary poisoning. Nelson (1970) refers to this effect as a biological chain reaction and his list includes hawks.

1080 is very soluble in water and does not break down with heat until $200^{\circ} \mathrm{C}$ is reached. Consequently, the poison is readily leached from the bait during spring thaws and is carried into the surrounding water. Perry (1970) queries, "How much 1080 is washed, during heavy rains, into our streams and absorbed by the root systems of our grasses?" (and hence into our livestock). And Cole, (1971), "What will be the ultimate effects on soil, vegetation and fauna from distributing the relatively stable and deadly 1080 throughout the [western United States] desert?" Perry (1970), in pressing a representative of a U.S.
1080 manufacturing company, received the answer: Yes, it was theoretically possible that " 1080 could accidentally leak into public water supplies and cause depressions, convulsions and deaths attributable to heart attacks and that no one would know the cause." And yet, when I objected to the Public Health Department because a bait station was to be set up onequarter mile from our house, I was told that there was no cause for concern.

1080 is tasteless, odorless, and is given the "most toxic" rating in "Clinical toxicology of commercial products" (Huxtable 1971). The dose for 100 per cent mortality in humans is variously quoted from $2 \mathrm{mg} . / \mathrm{kg}$. budy weight (Smelser, 1959) to $5 \mathrm{ml}$./ kg. (Huxtable, 1971). Using $2 \mathrm{mg} . / \mathrm{kg}$., a 30 -pound child eating two pounds of bait poisoned at the rate of $1.4 \mathrm{gm}$. 1080 per $100 \mathrm{lb}$. meat would die. This ingestion is unlikely, of course, but possibly children are more sensitive than this figure for an average human would indicate (for cats and dogs the legal dose is only $0.1 \mathrm{mg} . / \mathrm{kg}$.). In addi. tion, since the poison is not uniformly distributed in the meat (it is injected), it is possible that a small fraction of this amount could kill a child who happened upon one of these bait stations. I have neglected here the possibility of human error in dissolving the poison initially and this must have been a factor in at least some of the 16 confirmed human deaths caused by 1080 by 1956 (Smelser, 1959) or several dozen by 1971 (Huxtable). Nor is it a painless death. One man suffered for 17 hours and there is no known antidote (Smelser).

Does the amount of poisoning being done in Saskatchewan merit concern? Certainly, the number of baits set now is reduced considerably from the time when coyotes were prevalent in the late 1950 's. But as late as the winter of 1967-68, 89 municipalities and six local improvement districts set baits. Since then, according to $\mathrm{Mr}$. W. A. Hartwell, the acting Deputy Minister of Natural Resources at the time, the number of baits has been "substan- 
tially reduced in the frontier and northern areas, whereas the coverage in the south and particularly the southwest has remained at about the same level" (pers. corres. 1971). In the winter of $1970-71,38$ municipalities set out poison, as many as 10 bait stations per municipality.

Are these stations necessary, and are the restrictions on the use of 1080 stringent enough? According to $\mathrm{Mr}$. Hartwell, the bait placement is made as a result of specific agricultural damage complaints, but in reality the poison is available to any municipality requesting it, apparently without proof of damage. In one case, a station was set up near Regina, adjacent to a game preserve, because a farmer lost "a few chickens." If the poison program is going to continue, surely it is not too much to ask that the use be restricted to cases of excessive economic loss due to confirmed predation by coyotes. In view of 1080's danger, it is probably far cheaper to repay all farmer losses from the public purse than to subject the public to this hazard. This method was advocated by Arizona Rep. Morris Udall in a bill he introduced in the United States to provide coyote protection. The farmer alone should not pay the costs - if there are costs (see below) - of main. taining the coyote.

Also, although bait locations are advertised, many people are not aware that poison is present in their locality. It is my contention that all families within a two-mile radius of a proposed bait station should be warned that it will be set. In addition, I feel that such stations should be banned near urban areas, game preserves, and parks where families may take outings with children or dogs.

Even if restrictions were to be tightened, a major problem that cannot yet be overcome is the veritable impossibility of diagnosing a death due to 1080 (Olson, 1971, pt. 1). In describing to people familiar with poisoning the symptoms that our dog showed, I received about equal guesses of strychnine and 1080. Analysis of vomited bait revealed nothing. Thus it is possible for anyone who dislikes coyotes or dogs to obtain strychnine from their municipality (for gopher control) or even poisoned grain (for rats), use this in conjunction with meat and have the resulting deaths blamed on 1080 bait. This use of the poison is illegal but because 1080 is being used with DNR sanction the other can be set out with little fear of detection or consequence, and I suspect that many farmers and others are sure it is allowable. Until the use of 1080 is stopped, it will not be possible to have other instances of poisoning taken seriously by law enforcement agencies, or even DNR officers.

The Pest Control Products Act (Canada) allows for the "treatment of any control product to facilitate its recognition by change in coloration or other means." However, Hon. H. A. Olson, Federal Minister of Agriculture, states that "as yet there is no satisfactory tracer dye that shows up in a bird or animal that has eaten poisoned bait" (pers. corres. 1972). Thus, confirmed diagnosis is limited to rare cases when an expert analyzes the stomach contents very shortly after death. Diagnosis of secondary poisoning is not possible. It remains impossible to assess the extent of killing by this poison.

To try to determine whether, in spite of the disadvantages of 1080 , poisoning should be continued, let us now try to assess the value of the coyote. Certainly, the aesthetic appeal of the coyote is considerable. How many visiting campers leave disappointed, having come west expecting to share the pleasure expressed by Ernest Thompson Seton (in Young, 1951): "If ever the day should come when one may camp in the West, and hear not a note of the coyote's joyous stirring evening song, I hope that I shall long before have passed away, gone over the Great Divide." Frequently, visiting relatives and numerous schoolchildren who have tented near our home expressed regret after listening intently, and in vain. For my family, a recent northern holiday was made more memorable when coyotes seemed 


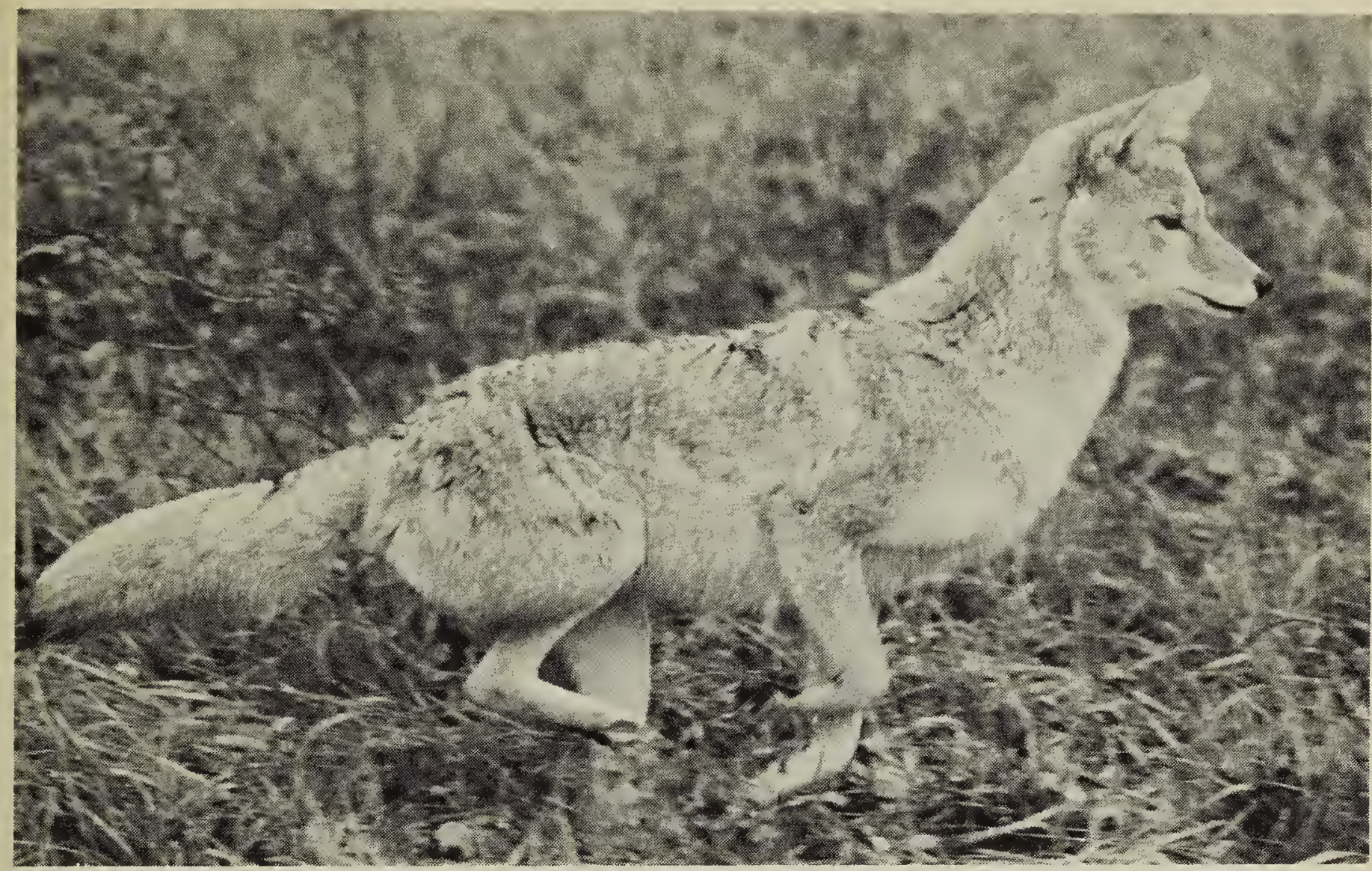

Coyote - running

Photo by Robert R. Taylor, Winnipeg

to ring our campsite and provide a lively serenade in stereo. The tourist appeal is recognized in Ontario's Algonquin Park, where people line up to hear wolves howl. Naturalists and conservationists appreciate the excitement engendered by the sight and sound of a coyote and this positive feature should not be overlooked by government departments.

The coyote's long-haired pelt is presently in strong demand. Both the 1969 and 1970 annual reports of DNR call coyotes lucrative species. The dollar values for the last four years are given in Table 1 . Those taken in the 1970-71 season represent 9.4 percent of the total fur harvest, and 88 per-

Table 1. Number and value of Coyote pelts taken in Saskatchewan during the last four winters.

\begin{tabular}{lrrr}
\hline Winter & $\begin{array}{r}\text { Pelt } \\
\text { value }\end{array}$ & $\begin{array}{r}\text { No. } \\
\text { taken }\end{array}$ & \multicolumn{1}{c}{$\begin{array}{c}\text { Total } \\
\text { value }\end{array}$} \\
\hline $1970-71$ & $\$ 11.97$ & 10,225 & $\$ 122,377.00$ \\
$1969-70$ & 12.35 & 8,316 & $114,313.05$ \\
$1968-69$ & 14.16 & 9,874 & $136,633.66$ \\
$1967-68$ & 7.67 & 3,294 & $24,429.16$
\end{tabular}

cent of them were from the southern region. Trapping in the south is often done by farmers and farmers' sons. Surely this amount of income is a sig. nificant advantage in these rural areas. Also, the 1969-70 pelt value was only 50 cents less than that of the beaver which is a vigorously protected species. It should be noted that the government earns a royalty of 50 cents per coyote pelt, a total of some $\$ 5,100$ in the $1970-71$ season.

For further evaluation of the coyote's worth, it is necessary to try to understand its ecological position. Many of the quoted figures concerning the food of coyotes are based on a study by C. C. Sperry for the United States Fish and Wildlife Service (in Young, 1951). Between 1931 and 1935, in all seasons and in 17 western and midwestern states, stomach conitents were examined from more than 8,000 coyotes. The results showed that rabbits were the most important food, occurring in 43 per cent of the stomachs, except in mid-winter when carrion was most common. Rodents appeared in one-third of the stomachs, livestock in one-fifth. On a volume of 
stomach content basis, rabbits constituted 33 per cent, carrion 25 per cent, rodents 17.5 per cent, livestock 13.5 per cent (mainly sheep and goat), deer 3.5 per cent (some of this may have been carrion) and birds (including poultry) 3 per cent. A list of food items of the coyote would include: carrion, lizards, toads, snakes, sheep, calves, pigs, deer, young elk, mountain sheep, grouse, quail, pheasants, ducks, turkeys, chickens, meadowlarks, other song birds, fruit and insect-eating birds, beaver, sage grouse, birds' eggs, wild and domestic fruits, prairie dogs, pocket gophers, ground squirrels, rabbits, field mice, porcupine, grasshoppers and beetles. The pamphlet "Wolves and coyotes of Ontario" (Ontario Department of Lands and Forests) calls the prey of the coyote "anything that is edible, either vegetable or animal", and notes that in that province rabbits, rodents, and small birds are the principal foods. A study in British Columbia in 1947 by J. A. Munro (in Young, 1951) noted the eating of a large amount of vegetable matter, but named the rabbit as principal food.

Stomach analysis alone must be viewed with some suspicion, however, because what a coyote eats is not necessarily equivalent to what it destroys. It is a clever animal, quick to take advantage of unusual situations. One example of its cleverness is its habit of following fence lines, picking up the dead grouse which have collided with fence wires. Coyotes also watch for magpies on colts and fawns because this may indicate that the birds are picking up ticks which sometimes paralyze their hosts (Dobie, 1949).

Keeping all these forms of feeding in mind, we can ask what, then, is the overall harm or benefit of the coyote as a species. A difficult question to answer, certainly, but in attempting to do so, I shall consider some of the effects of the animal on carrion, game animals, rodents, insects, and livestock.

Its carrion-eating habits are generally beneficial. Dr. E. R. Hall (in Van
Wormer, 1964) states: "He (the coyote) is a health officer among game and other animals, including man himself. For one thing, he is a scavenger, and on watersheds which supply water for domestic use, he retrieves many a carcass for food that otherwise would decay and contaminate the water supply, or serve as a lure to filth-loving insects which carry the organisms of decay to man's food."

With respect to game animals, predation helps to maintain the quality of prey species by cropping the weak, disabled and diseased (Nelson, 1970; Perry, 1970; Ont. Dept. Lands and For. ests). Without this natural control, deer, elk and moose may increase to levels beyond the capacity of the habitat to support them, in which case habitat destruction and starvation result (Nelson, 1970; Olson, 1971). Except in deep, crusty snow or under special conditions such as the migration of antelope across the South Saskatchewan River (Young, 1951), it would seem that healthy game animals are difficult prey for coyotes. For one thing, coyotes usually hunt alone or in pairs, rather than in packs (Young, 1951; Ont. Dept. Lands and Forests), and deer and antelope are often able to outrun them (Van Wormer, 1964). Also, deer have even been known to chase coyotes and stamp on them (Young, 1951). The Ontario goverment publication states that there are no authentic reports of coyotes attacking deer in that province. It is possible that a significant proportion of the stomach content evidence of deer predation represents animals that were near death, due to sickness or injury (eg. by hunters or automobiles). Mr. Hartwell (pers. corres., 1971) stated that baits are not needed for predators of natural wildlife species (i.e. deer) in Saskatchewan.

Coyotes prey on several pests, such as mice, rats, and insects, and although Young (1951) suggests that this probably does little to prevent plagues of these animals, others strongly stress the advantage of this predation. C. F. Barrett, pest control officer 
with the Saskatchewan Department of Agriculture has stated (Barrett, 1970) that perhaps the tremendous rise in the number of rodents is due in part to the way we have depleted coyotes and skunks. Then, of course, the fact that a rodent poisoning campaign must eventually be undertaken when this natural control is gone is a new expense and hazard (Nelson, 1970; Perry, 1970; Barrett, 1970). In fact, Cole makes the interesting observation that with the decrease of predatory birds, the mammalian enemies of rodents become increasingly valuable. Regarding insects, the fact that 71 per cent of one young coyote's stomach contents were grasshoppers (Van Wormer, 1964) indicates some benefit to man. A flyer issued by the Monte Nido Horsemen's Association, Calabasca, California, praises predators thus: "Stop-don't kill coyotes or foxes - they are our allies. They kill germ-infested rodents and . . . are nature's own non-poisonous pesticide. For every dollar they cost you, they will repay twenty."

There may be some advantage in the coyote as a counter against the red fox, with which it competes. According to Hugo Maliepaard, DNR (pers. corres.), there has been a tremendous increase in foxes along with the decrease in coyotes in Saskatchewan since the late 1950 's. These predators may pose an even greater control problem than the coyote because they are reluctant to take carrion and hence are harder to poison.

The main proponents of coyote control programs are ranchers, intent on protecting livestock. I was unable to obtain figures on livestock damage in Saskatchewan, but apparently the biggest concern lies with sheep, calves and poultry. Although individual ranchers may suffer considerable losses to coyotes, the total economic picture must be considered, and this is complex. As an example, Dobie (1949) points out that "a coyote that means loss on a poultry farm may be a positive gain in an alfalfa field where gophers are working." Perry (1970) attempts an analysis of the situation during 1969 in Arizona: 1864 coyotes killed at a cost of $\$ 80.88$ per coyote (!) - \$157,603. Estimate of stock killed by coyotes - 539 sheep, 375 poultry, 182 cattle, 41 pigs, 17 goats, 3 dogs and cats, 2 horses-value of $\$ 42,225$. The program, then, represented a net cost of $\$ 115,378$. In addition, Perry points out that coyote control jack rabbits which compete with stock for forage, especially on depleted or overgrazed range. He suggests that 148 blacktailed jack rabbits consume the forage that could support one cow, or five sheep. Assuming that five coyotes would destroy this number of rabbits in a year, the 1864 coyotes killed in 1969 were equivalent to range forage for 373 cattle - worth about $\$ 53,000$. In other words, the value of the coyotes in controlling forageeating rabbits exceeded the loss in livestock.

This benefit to farmers was pointed out back in the early 1950's by the Toponas Grassland Protective Association (Van Wormer, 1964). The organization's claim was that for 10 years they had seen a steady increase in mice, gophers, moles and rabbits to the point where these were taking up to one-third of the hay crop, and cutting

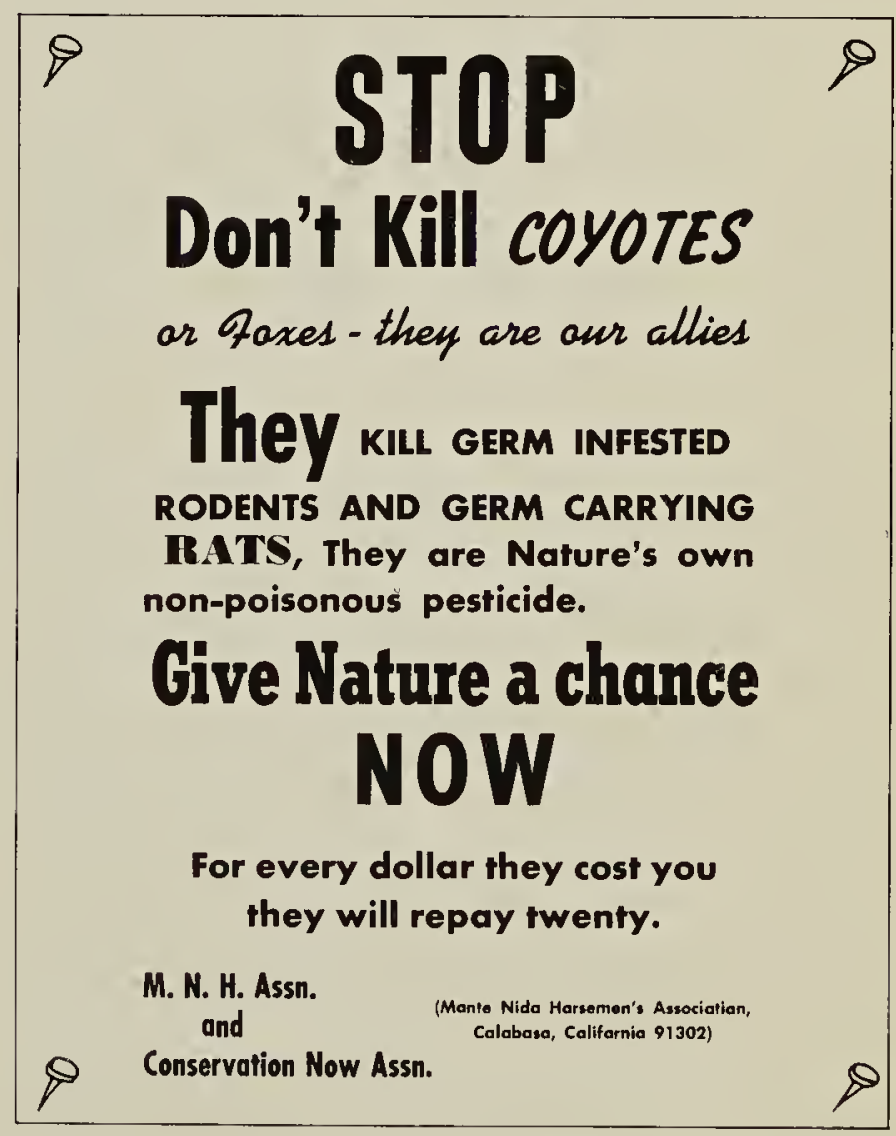

Poster, DWN, Spring 1971 
the carrying capacity of the range lands by one-half. The association condemned the use of poison (especially 1080 which it called a deadly chain killer) and stated that on the land of their members, the coyotes were to "live without persecution and to increase in numbers so that they can once again play the role that nature intended, and be an effective check on the rodent population."

The theories of Alfred Etter on coyote ecology, as outlined by Olson (1971, pt. 3) should be examined. Etter suggests that the coyote, if left alone, will choose a territory, exist on small prey, and probably not bother sheep or cattle. One government trapper, for example, tried to kill a pair of coyotes for nine years but only succeeded in getting the pups. When he finally got the parents, "strangers" moved in and a real probem with predation on sheep developed, whereas before there had been none. Etter claims, also, that if human control of coyotes were abandoned, abnormal increases might occur but only until territories were established by the stronger animals. Perry (1970) points out that sheep loss in Arizona, where a strong control program exists, represents 0.10 per cent of sheep and lambs on Arizona ranches, and on the Lava Beds National Monument of California, where no controls are used on the flourishing coyote and bobcat population, the loss to predators was essentially the same at 0.12 per cent. In this case, natural controls seem as effective as poison controls.

The failure of the poison control programs may be in part due to the disruption of territories, causing more coyotes to turn to livestock, but it is also due to the fact that poison is not selective. Numerous authors suggest that the "problem" coyotes are the old, weak, or maimed (Maliepaard, pers. comm.; Ont. Dept. Lands and Forests). Van Wormer (1964) says that a crippled coyote will consume 50 per cent, more livestock than a normal one. Poison, of course, kills any that will eat it - and perhaps these older ones are too crafty to eat the poison. This same non-selective problem was seen with the bounty system (Paynter). It would seem that where coyotes are creating a real problem, the ideal solution is live-trapping (Nelson, 1970; Ont. Dept. Lands and Forests). In this way, only coyotes need be taken; the animal remains at the site so it is possible to know when a particular "miscreant", perhaps a cripple, has been captured; the pelt may be usable; and the system is humane.

One further reason for coyote control was put to me by a DNR officer, the fact that coyotes can carry rabies. Although I was not given the numbers of rabid coyotes encountered, I very much doubt if the situation is different from that which prevails in Ontario where "coyotes do not appear to be commonly affected by rabies." Raymond Bock, M.D. (1970) claims that the answer to rabies control lies in the inmunization of domesticated animals, since 90 per cent of all reported rabid animal bites are from the dog, and 8 per cent from other domestic animals including cats, horses, and cattle. The 2 per cent remaining are from wild animal pets and wild animals. Bock further points out that rabies often sweeps through an area when a population of animals is in peak numbers. The survivors are immune and keep the area relatively free from rabies for many years. It is not logical for man to try to exert control by killing large numbers of animals, immune and suspectible alike.

Some provinces are recognizing the value of the coyote and the wolf. The Manitoba Department of Mines, Resources and Environmental Management adopted the wolf as its symbol, with the explanation, "we are also undertaking to see that it [the wolf] gets the necessary protection to maintain a reasonably abundant population. It means we understand (or try to understand) the complex interrelationships of nature [and] we recognize the value of all life forms" (Mair, 1970). This approach is reflected also in a publication by the same department entitled, "The wild dogs - a story of wolves in Manitoba." A pam- 
phlet published by the Ontario government advocates management of the coyote, "on the same basis as other game animals - control when and where needed, and freedom from control when it is not required." On the other hand, I understand that Alberta still has an active coyote control program which favors the use of poison.

The DNR is now undertaking a study of the ecology of the coyote in Saskatchewan and until this is complete it will be difficult to assess the need for coyote control in this province. However, it would seem wise for conservation groups and interested individuals now to demand that that study answer at least these questions: What is the actual annual livestock loss which can be directly attributed to predation by the coyote? What is the advantage of the coyote in terms of its preying on rabbits, mice, rats, and insects? What is the balancing effect of the coyote on the red fox population?

In addition, because coyote ecology is tied up with the use of 1080 or other forms of control, these questions should be asked: What is the annual loss of other animal species due to the use of 1080 ? (Unfortunately, this question cannot be satisfactorily answered because the animals in question are not located and cause of death cannot be diagnosed.) What is the total cost of the 1080 poisoning program? What is the possible pollution effect of 1080 ? Why is a trapping system of coyote control not introduced in those circumstances for which control is proven necessary? Is financial compensation to farmers not the cheapest way, in terms of economics and ecology, to deal with livestock losses due to coyote predation?

At present, the DNR is bowing to pressure from some agricultural groups. I have a letter dated December 15, 1971 from Hon. E. Kramer, then Minister of Natural Resources, assuring me that the Department was "very concerned with the role the coyote plays in the balance of nature." Yet, shortly thereafter, without waiting for the results of his coyote study, he announced that snowmobile hunting of coyotes would be permitted. The fact is that there is no clear policy on coyotes. Reading the Fur Act, Game Act, Rural Municipality Act, and Pest Control Act leaves me (and probably civil servants as well) totally confused. It is time to demand an end to poisoning and the start of protection for the coyote, either as a game animal or a fur bearer — strongly, loudly, and repeatedly. Also, if the government does adopt such a protective policy, it is mandatory that that policy be clearly stated and widely advertised, and that there be stiff penalties for abuse. Only then will the public, when they encounter cases of wanton destruction, be in a position to demand action of law enforcement officials.

\section{LITERATURE CITED}

Barrett, C. F. 1970. More mice and rats. Western Producer, Aug. 6.

Bock, R. F. 1970. Rabies. Defenders of Wildlife News. $45(3): 290-291$.

Cole, G. A. 1971. An ecological gap. Defenders of Wildlife News. $46(1): 40-41$.

Dobie, J. F. 1949. Voice of the coyote. Little, Brown.

Huxtable, R. 1971. The actions of poisons. Defenders of Wildlife News. $46(1): 42$ and 46(3), 324-330.

Mair, W. W. 1970. Wolf is Manitoba resource symbol. Defenders of Wildlife News. $45(3)$ : 265.

Nelson, G. Sen. (Wisconsin). 1970. Introduction of a bill to establish a national policy with respect to wild predatory mammals, and for other purposes. Defenders of Wildlife News. $45(4): 367-369$.

Olson, J. 1971. Poisoning of the West. Sports Illustrated. pt. 1 Mar. 8; pt. 2 Mar. 15; pt. 3 Mar. 22.

Ontario Department of Lands and Forests. Wolves and coyotes in Ontario. A publication of the Fish and Wildlife Branch and the Research Branch of the Ontario Government.

Paynter, E. L. 1967. The coyote control program. Misc. paper No. 1, Saskatchewan Department of Natural Resources, Regina.

Perry, H. L. 1970. Predator control notes from Arizona. (and) Our poisoned land. Defenders of Wildlife News $45(1): 25-51$.

Phillips, J. 1971. Eagles on the decline. Leader-Post, Regina, Sept. $2: 18$.

Saskatchewan Department of Natural Resources. 1969. The 1968-69 coyote control program. Game Division, Wildlife Branch, mimeo.

Saskatchewan Department of Natural Resources, 1968, 1969, 1970. Annual reports of the department. Queen's Printer, Regina.

Smelser, M. A. 1959. Uncontrollable "control". Nature Magazine, $52: 33-40,50$.

Van Wormer, J. 1964. The world of soyote. I.ippincott.

Young, S. P. 1951. The clever coyote. Stackpole. 